
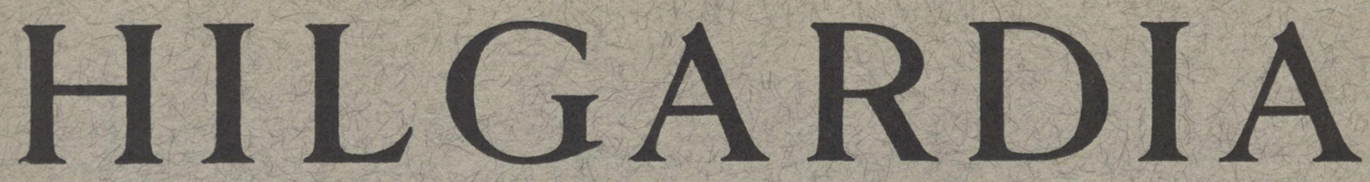

A Journal of Agricultural Science Published by the California Agricultural Experiment Station

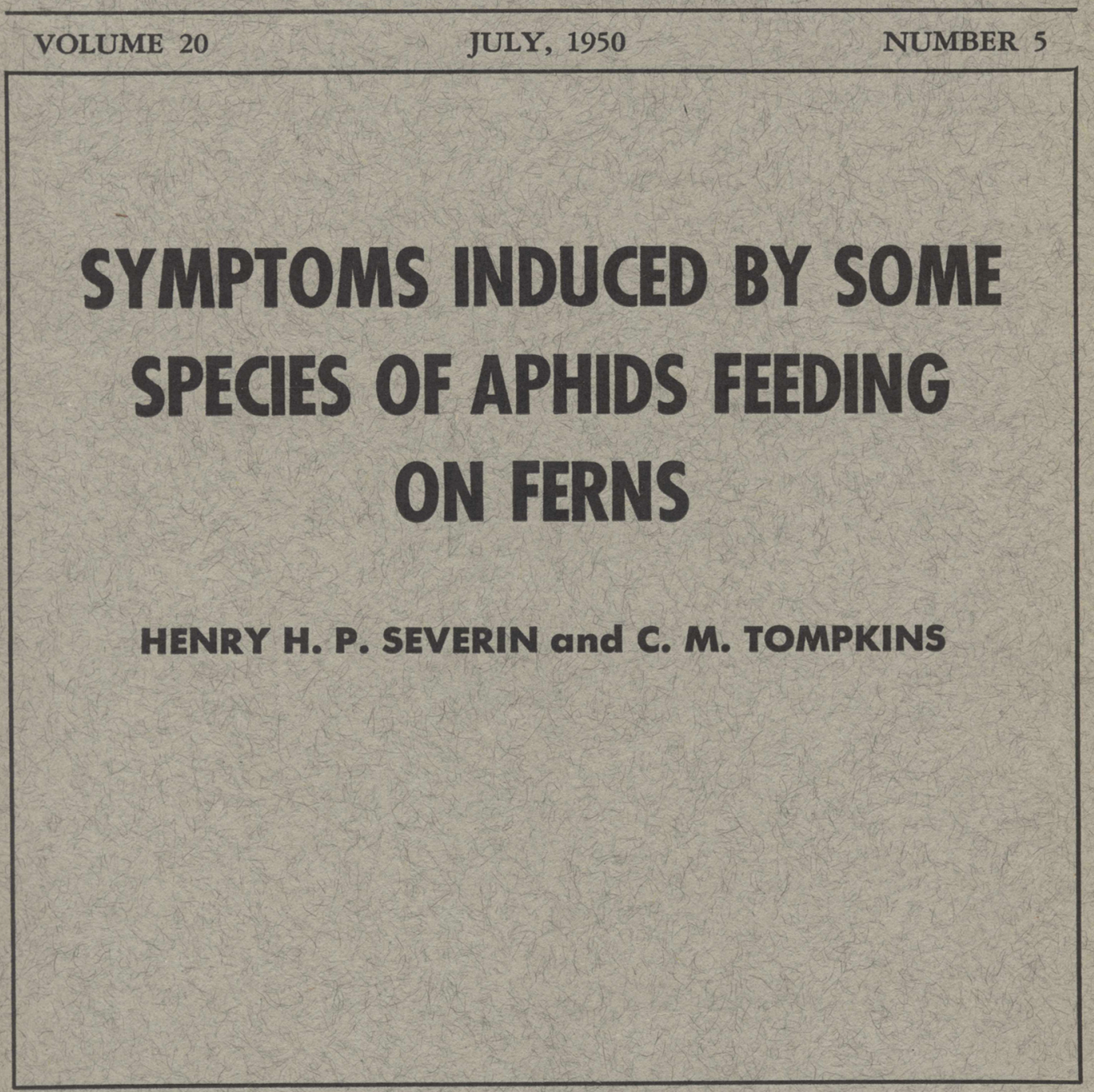

UNIVERSITY OF CALIFORNIA - BERKELEY, CALIFORNIA 


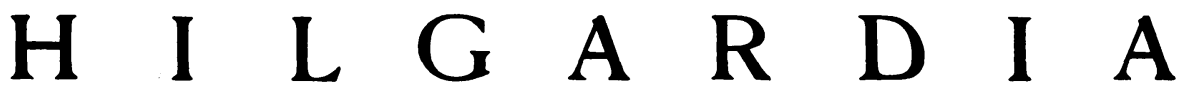

A Journal of Agricultural Science Published by

the California Agricultural Experiment Station

VoL. 20

JULY, 1950

No. 5

\section{SYMPTOMS INDUCED BY SOME SPECIES OF APHIDS FEEDING ON FERNS ${ }^{1}$}

\author{
HENRY H. P. SEVERIN ${ }^{2}$ and C. M. TOMPKINS ${ }^{3}$
}

DURING THE PAST five years, 25 large birds-nest ferns (Asplenium nidus) have been kept in a greenhouse at the University of California, Berkeley. In the spring of 1949 five of these plants developed chlorotic circular and spindleshaped areas extending laterally from the midrib (plate 1) on the fronds. No aphids were found on any of the plants.

On May 10, 1949, two large birds-nest ferns with dark green streaks on the fronds were found in a greenhouse in San Francisco. One hundred small plants were obtained from the same nursery, and after transplanting in five-inch clay pots, ten plants developed dark green streaks on several of the youngest fronds. No symptoms appeared on the newly developing fronds. Again no aphids were found on birds-nest ferns in greenhouses in San Francisco and San Mateo Counties.

\section{REVIEW OF LITERATURE}

Severin, Horn, and Frazier $(1945)^{4}$ reviewed the literature on plant symptoms induced by the feeding of a leafhopper, and described certain symptoms, resembling those of curly top and aster yellows, induced by the saliva of Xerophloea vanduzeei Lawson. On sugar beets (Beta vulgaris) the saliva induced cleared veinlets, previously considered a reliable symptom of curly top. On China aster (Callistephus chinensis) it caused cleared venation with yellow veinbanding, stunting of the plants, development of axillary shoots from the bud in the axil of the leaves, and virescence of the flowers, all symptoms being similar to those of aster yellows. The most striking effect produced by the feeding of the leafhoppers was color-breaking in the petals of asters.

In a recent paper, Severin (1947) described the symptoms induced by ten species of noninfective leafhoppers, all vectors of the California-aster-yellows virus, on the leaves of healthy China aster, Golden Self-Blanching celery (Apium graveolens var. dulce), and sugar-beet plants. Nymphs of Idiodonus heidemanni Ball are yellow in color, and each nymph in feeding on an aster leaf causes a yellow discoloration, presumably serving as a protective resem-

\footnotetext{
${ }^{1}$ Received for publication October 15, 1949.

2 Entomologist in the Experiment Station, Berkeley.

Associate Plant Pathologist in the Experiment Station, Berkeley.

- See "Literature Cited" for citations referred to in text by author and date.
} 
blance. Since but one nymph will induce these symptoms, a toxic salivary secretion is probably involved.

As reported in previous papers (DeLong and Severin, 1948, and Severin, 1948) the following species of leafhoppers, vectors of the California-asteryellows virus, were collected under natural conditions on bracken (Pteridium aquilinum) belonging to the Polypodiaceae or common-fern family: Calladonus commissus (Van Duzee), Friscanus intricatus (Bell), F. rupinatus (Ball), and $F$. rupinatus var. brunneus Delong and Severin. No leafhoppers were found on birds-nest fern, holly fern (Cyrtomium falcatum), or maidenhair ferns (Adiantum concinnum variety Geneva Glory and $A$. cuneatum var. croweanum variety Pacific Maid) in greenhouses in San Francisco and San Mateo Counties.

It is a well known fact that species of aphids produce various symptoms on the leaves of their host plants. Severin and Freitag (1938) reported that species of noninfective aphids feeding on healthy celery plants induced abnormalities of the leaflets. The cotton or melon aphid, Aphis gosypii Glover, feeding on the foliage of celery plants caused curling of the leaflets. Noninfective yellow willow aphids, Cavariella aegopodii (Scopoli), feeding on healthy celery plants produced a pronounced yellowing along the cleared veins and a marked chlorosis of the leaflets, probably caused by the saliva of the aphids. The foxglove aphid, Myzus solani (Kaltenbach), feeding on the leaflets of healthy celery plants induced white.spots, the latter resembling the symptoms of the celery-yellow-spot virus except in color.

In our work on cauliflower mosaic, Severin and Tompkins (1948) found that feeding of cabbage aphids, Brevicoryne brassicae (L.), causes symptoms on cauliflower (Brassica oleracea var. botrytis) aside from those caused by the virus. The leaves of cauliflower seedlings on which either noninfective or infective cabbage aphids had fed showed circular chlorotic areas around the mouth-part punctures. The newly developing leaves on which no aphids had fed failed to show this symptom; hence the effect is local and not systemic.

In our work on mild mosaic of annual stock (Matthiola incana var. annua), Severin and Tompkins (1948) reported that noninfective as well as infective turnip or false cabbage aphids, Rhopalosiphum pseudobrassicae (Davis), produced pale green circular areas around the mouth-part punctures on the leaves.

In a recent paper, Severin and Tompkins (1949, unpublished) found that the foxglove aphid produced malformed leaves with blisterlike elevations on Primula obconica. After the plants had been fumigated to kill the aphids, new leaves developed normally.

In another recent paper Severin (1949, unpublished) reports that noninfective erigeron-root aphids, Erigeron middletoni Thomas, induced small, chlorotic, circular areas around the feeding punctures on the leaves of Pelargonium hortorum. Noninfective foxglove aphids, Myzus solani, produce similar chlorotic spots, also distortion on the leaves of $P$. hortorum, and savoying or blistering on the leaves of ivy geranium ( $P$. peltatum).

Unpublished research by Severin and Tompkins indicates that noninfective foxglove aphids feeding on the leaves of Freesia refracta grown from seeds induced small white areas around the mouth-part punctures. Severin found 
that this species of aphid causes circular, chlorotic spots around the mouthpart punctures, streaks, and blisterlike elevations on the leaves of China aster.

\section{METHOD}

The production of noninfective aphids has been described in a number of papers (Severin and Freitag, 1938; Severin and Drake, 1948; and Severin and Tompkins, 1948a).

\section{APHID SPECIES COLLECTED ON FERNS IN GREENHOUSES}

The following species of aphids were collected on the Geneva Glory and Pacific Maid varieties of maidenhair fern in greenhouses in the San Francisco Bay area:

Fern aphid, Idiopterus nephrelepidis Davis.

Macrosiphum pteridis Wilson ${ }^{5}$

Lily aphid, Myzus circumflexus (Buckton)

Foxglove aphid, Myzus solani (Kaltenbach)

\section{SYMPTOMS ON FERNS}

Foxglove Aphids. Noninfective foxglove aphids feeding on the fronds of birdsnest ferns induce circular, chlorotic areas (plate 2, $A$ ), which later become spindle-shaped (plate $2, B, C$ ), extending laterally from the midrib and resembling beads (plate $2, E$ ). The newly developing fronds are chlorotic with few green areas (plate $2, F, G$ ).

When lots of one, five, ten or 20 noninfective, wingless foxglove aphids were transferred with a fine camel's-hair brush from healthy celery leaflets to the youngest frond of each of 20 small birds-nest ferns, the intensity of the symptoms which developed varied according to the number of aphids on each plant. Single aphids produced a blanching along the midrib and lateral stripes (plate $3, A$ ), five aphids caused chlorosis along the midrib and lateral stripes which fused (plate $3, B$ ), ten aphids induced severe blanching with few green areas (plate $3, C$ ), and 20 aphids produced almost complete chlorosis (plate $3, D$ ). Symptoms frequently appeared on one or three newly developing fronds. When 100 aphids were fed on the youngest frond, as many as four newly developing fronds might show symptoms (plate $3, E$ ) after several months. The first symptom on the youngest frond appeared in five days.

When leaf cages (plate 5, B) containing one, five, ten, or 20 foxglove aphids were fastened to the youngest fronds of 20 birds-nest ferns, symptoms might develop only on the fronds covered by each detached leaf cage (plate $4, A$ ), or might spread above (plate $4, B$ ), below, above and below (plate $4, C$ ) and on sides of the encaged leaf (plate $4, E$ ). Symptoms might develop later on one (plate $4, F$ ) or two newly developing fronds.

When leaf cages containing one, five, ten or 20 foxglove aphids were fastened to one of the oldest fronds, mild symptoms appeared on the youngest leaf and sometimes on one or two of the newly developing fronds. Ten plants showed symptoms, but no symptoms appeared on ten other plants on which the aphids had fed.

\footnotetext{
${ }^{5}$ According to E. O. Essig (personal interview) this species of aphid occurs on bracken (Pteridium aquilinum).
} 
The symptoms induced by the feeding of the foxglove aphids on the fronds of holly ferns consists of chlorotic circular areas or streaks resembling beads along the midribs and veins (plate $5, A$ ). When all of the fronds were cut off, symptoms appeared on the newly developing fronds, indicating a systemic effect.

Fern Aphids. Symptoms induced by the fern aphids, Idiopterus nephrelepi$d u s$, on birds-nest fern consisted of dark green areas and veinbanding on the youngest fronds (plate $6, A$ ), and dark green veinbanding on older fronds (plate 6, B). Similar symptoms appeared on one or two newly developing fronds. As the youngest frond became older, larger dark green, irregular areas covered several lateral veins and interveinal spaces. The oldest fronds upon which the aphids had fed were severely distorted. The first symptoms on the inoculated fronds appeared in from one to two weeks.

When lots of 20 aphids were fed on the youngest frond of birds-nest ferns for period of 15, 30, and 60 minutes, circular, chlorotic areas appeared on 14 of 15 plants in five days.

\section{APHID SPECIES WHICH FAILED TO INDUCE SYMPTOMS}

Numerous tests were made with Macrosiphum pterides and lily aphid, Myzus circumflexus, which were collected and multiplied on two varieties of maidenhair ferns, but these two species of aphids failed to induce symptoms by feeding on the fronds of birds-nest ferns.

The following species of aphids which have not been collected on ferns, and do not multiply on two birds-nest ferns in the greenhouse, failed to induce symptoms by feeding on the fronds of birds-nest ferns :

Celery aphid, Aphis apii Theobald $^{6}$

Rusty-banded aphid, Aphis ferruginea-striata Essig

Cotton or melon aphid, Aphis gosypii Glover

Bean or dock aphid, Aphis rumicis L.

Cabbage aphid, Brevicoryne brassicae (L.)

Yellow willow aphid, Cavariella aegopodii (Scopoli)

Pea aphid, Macrosiphum pisi (Kaltenbach)

Ornate aphid, Myzus ornatus Laing

Green peach aphid, Myzus persicae (Sulzer)

False cabbage or turnip aphid, Rhopalosiphum pseudobrassicae (Davis)

\section{MECHANICAL INOCULATION}

Extract from Fronds Showing Symptoms. The extract from symptom-displaying fronds of birds-nest ferns upon which the foxglove aphids had fed was inoculated by the carborundum method (Rawlins and Tompkins, 1946) into all of the fronds of 20 healthy plants, but no symptoms developed.

With Crushed Foxglove Aphids. Mechanical inoculation of all fronds of 20 birds-nest ferns with 0.2 and 1.6 grams of foxglove aphids crushed in 5 and 8 ce of sterile distilled water, respectively, failed to induce symptoms.

${ }^{\circ}$ According to E. O. Essig (personal interview), Aphis apii Theobald may be identical with A. helianthi Monell. 


\section{ACKNOWLEDGMENT}

We are deeply indebted to E. O. Essig, who determined the species of aphids for us.

\section{SUMMARY}

The following species of aphids were collected on maidenhair ferns (Adiantum concinnum variety Geneva Glory, and A. cuneatum var. croweanum variety Pacific Maid) :

Fern aphid, Idiopterus nephrelepidis Davis

Macrosiphum pteridis Wilson

Lily aphid, Myzus circumflexus (Buckton)

Foxglove aphid, Myzus solani (Kaltenbach)

The foxglove aphid feeding on the fronds of birds-nest ferns (Asplenium nidis) induces circular, chlorotic areas, which later become spindle-shaped, resembling beads, and extending laterally from the midrib. The spindleshaped beads become more numerous and often fuse, and chlorosis extends along the midrib. The intensity of the symptoms which develop varies according to the number of aphids on each plant. When 100 aphids are fed on the youngest frond, as many as four newly developing fronds may show symptoms after several months. The first symptom on the youngest frond appears in five days.

The first symptom produced by the foxglove aphid feeding on the fronds of holly fern (Crytomium falcatum) consists of chlorotic streaks resembling beads along the midrib and veins. When all of the fronds were cut off, symptoms appeared on the newly developing fronds, indicating the systemic influence of the causative agent.

The symptoms induced by the fern aphids, Idiopterus nephrelepidus, on birds-nest ferns consist of dark green interveinal areas and dark green veinbanding on the youngest frond. Similar symptoms appear on one or two newly developing fronds. When all of the fronds are cut off, symptoms appear on the newly developing fronds of some plants. The oldest fronds upon which the aphids have fed are severely distorted. The first symptom on the fronds appears in from one to two weeks. 


\section{LITERATURE CITED}

DeLong, D. M., and H. H. P. Severin

1948. Characters, distribution, and food plants of leafhopper species in Thamnotettix group. Hilgardia 18(4):185-99.

RAwLins, T. E., and C. M. ToMPKins

1936. Studies on the effect of carborundum as an abrasive in plant virus inoculations. Phytopathology 26(6) :578-87.

SEvERIN, H. H. P., and J. H. FreitTaG

1938. Western celery mosaic. Hìlgardia $11(9): 493-558$.

SEVERIN, H. H. P., F. D. HoRN, and N. W. Frazier

1945. Certain symptoms resembling those of curly top or aster yellows, induced by saliva of Xerophloea vanduzeei. Hilgardia. 16 (7) :335-60.

SEverin, H. H. P.

1947. Plant symptoms induced by feeding of some leafhopper species. Hilgardia 17(5): 219-26.

1948. Transmission of California-aster-yellows virus by leafhopper species in Thamnotettix group. Hilgardia 18(4):203-16.

SEverin, H. H. P., and C. M. ToMPKinS

1948a. Aphid transmission of cauliflower-mosaic virus. Hilgardia 18(11) :389-404.

1948b. Aphid transmission of mild-mosaic virus of annual stock. Hilgardia 18(15): 539-52. 


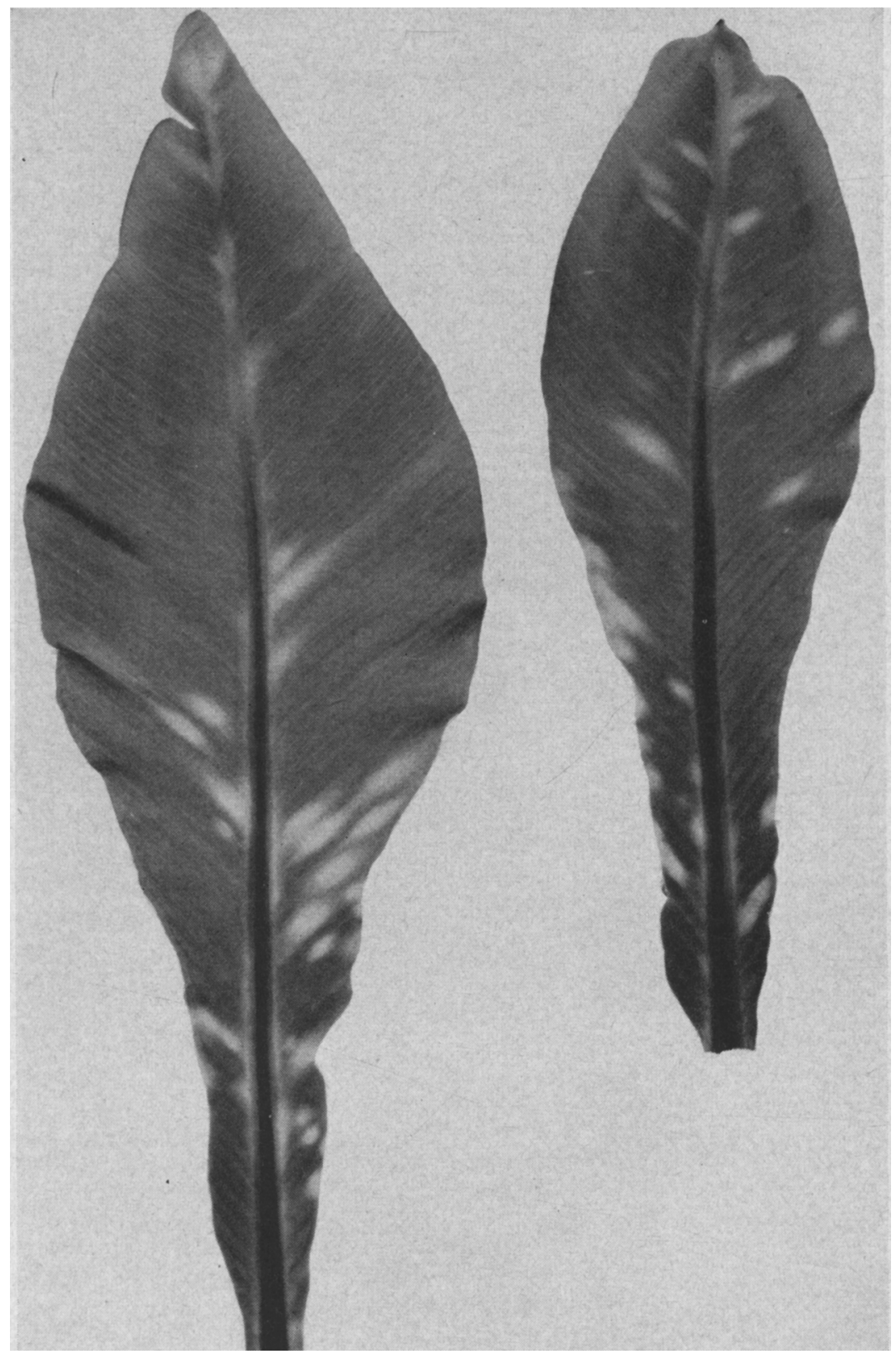

Plate 1. Chlorotic circular areas near base of frond, and spindle-shaped areas extending laterally from the midrib on frond of birds-nest fern found in the greenhouse at the University of California, Berkeley. 


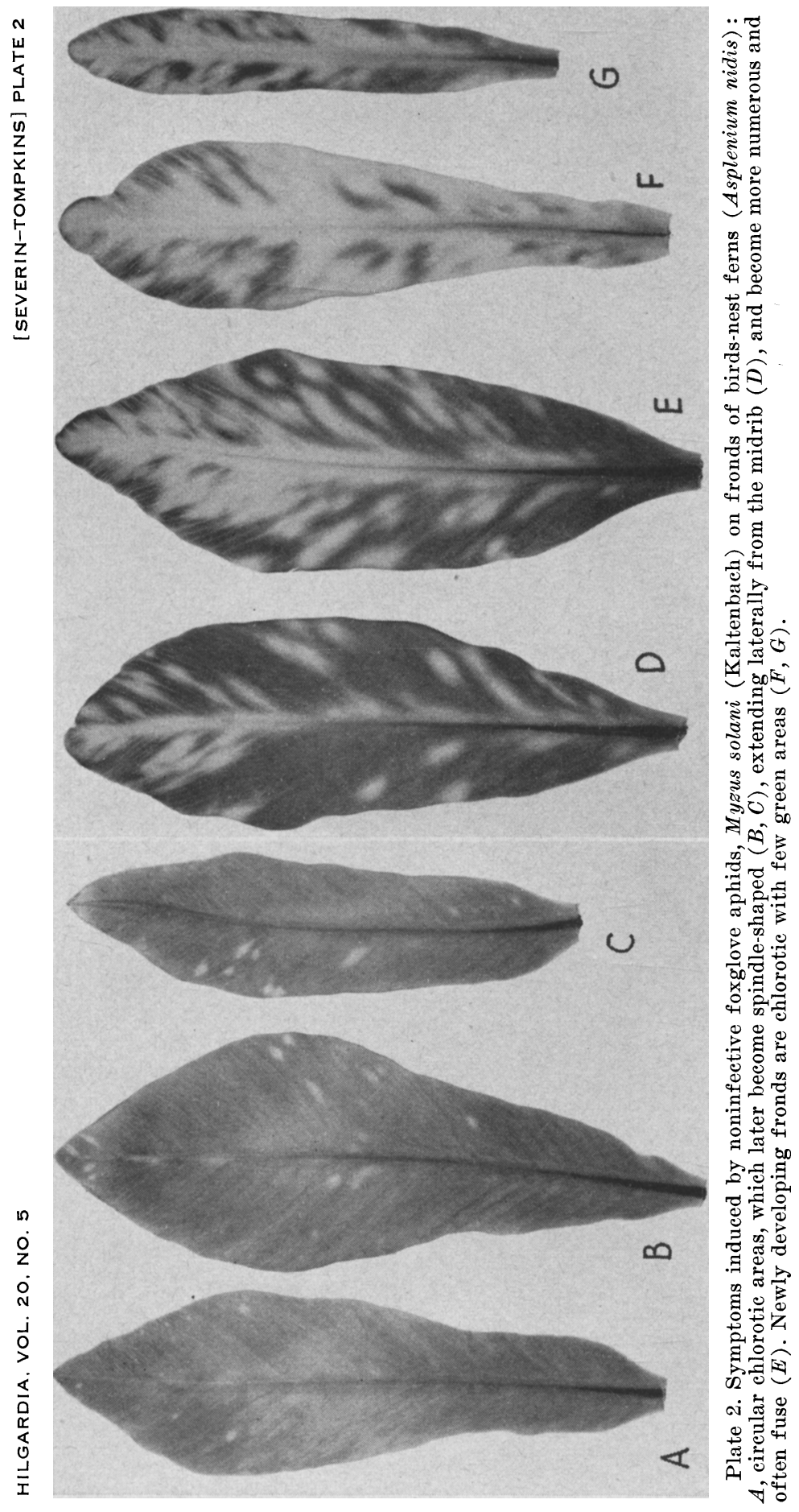




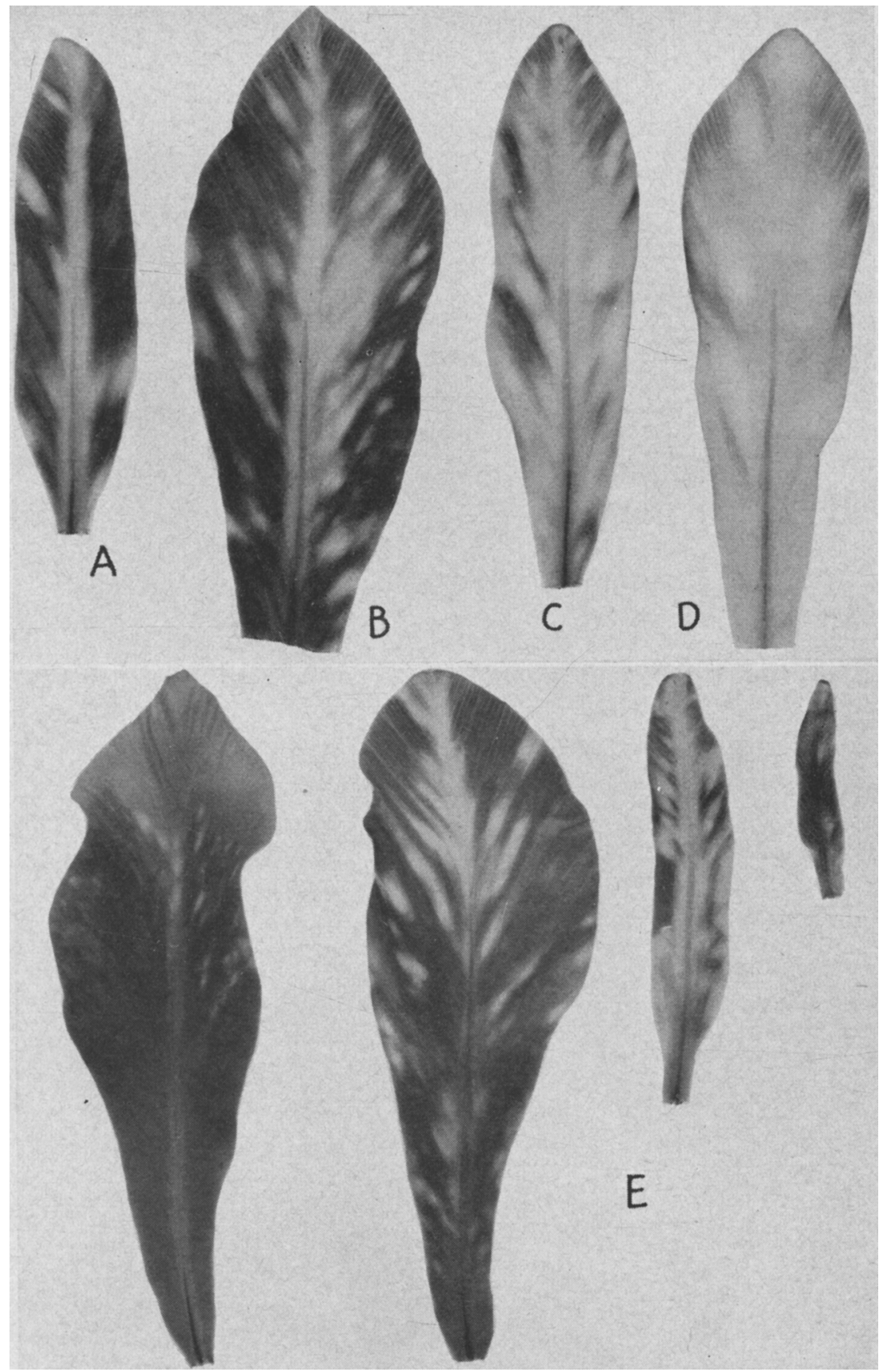

Plate 3. Symptoms induced by feeding of varying numbers of foxglove aphids, Myzus solani (Kaltenbach) on youngest frond of birds-nest fern (Asplenium nidis): $A$, blanching along midrib and lateral stripes produced by a single aphid; $B$, chlorosis along midrib, lateral stripes which often fused caused by five aphids; $C$, severe blanching with few green areas induced by ten aphids; $D$, almost complete chlorosis produced by 20 aphids. $E$, successive symptoms on four newly developing fronds not inoculated, from one plant. 


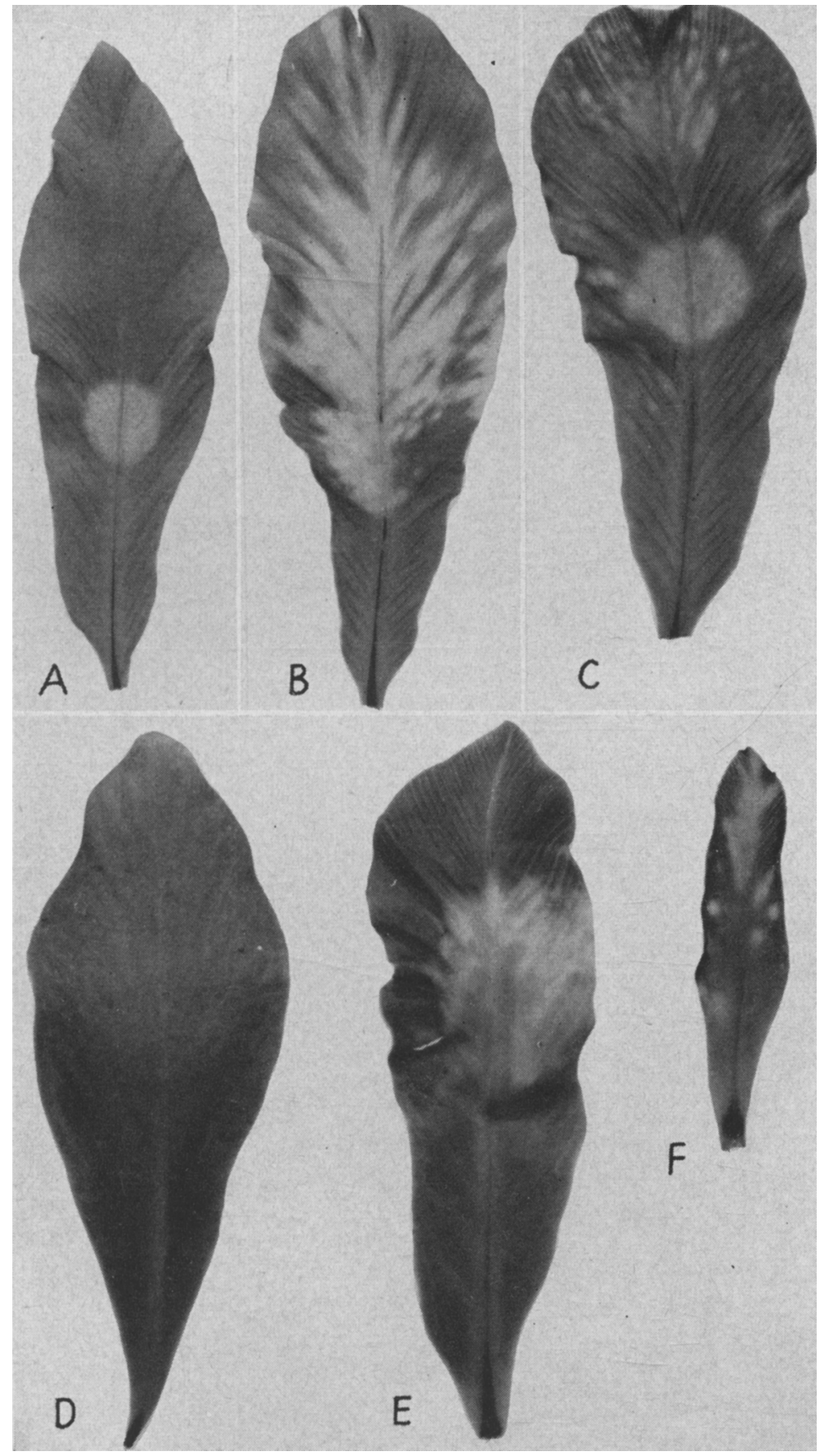

Plate 4. Symptoms included by one, five, ten, or 20 foxglove aphids, Myzus Solani (Kaltenbach), each confined in a leaf cage (Plate $5, B$ ) fastened to the youngest frond of birds-nest ferns (Asplenium nidis): $A$, symptoms developed only on the frond covered by detached leaf cage; $B$, symptoms above, $C$, above and below, and $E$, on sides of detached leaf cages. $D$, frond from healthy plant. $F$, eymptoms on newly developing frond, 


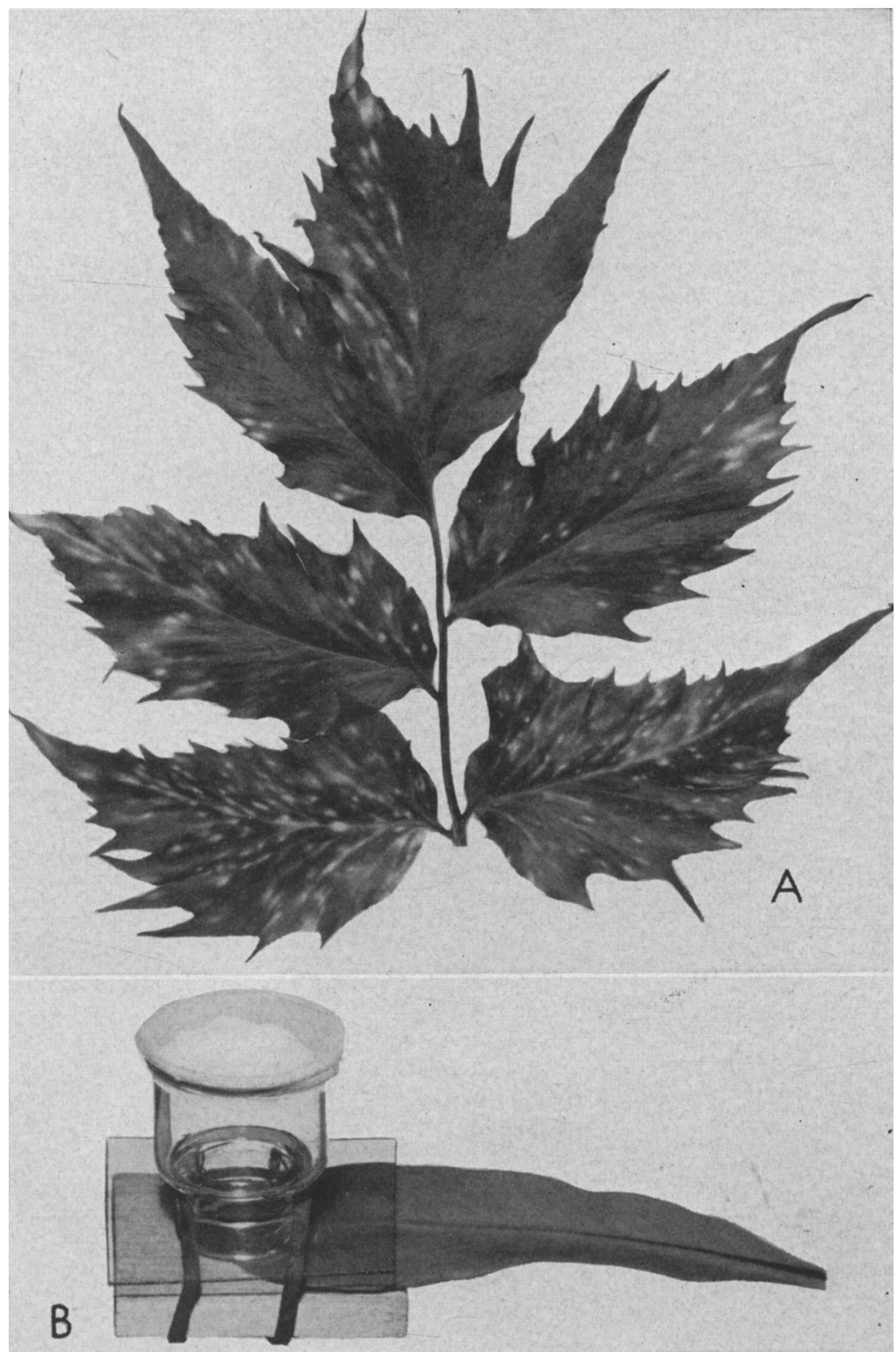

Plate 5. Symptoms induced by feeding of foxglove aphids, Myzus solani (Kaltenbach) on frond of holly fern (Cyrtomium falcatum): $A$, chlorotic circular areas and streaks resembling beads along midribs and veins; $B$, leaf cage attached to frond of birds-nest fern. 

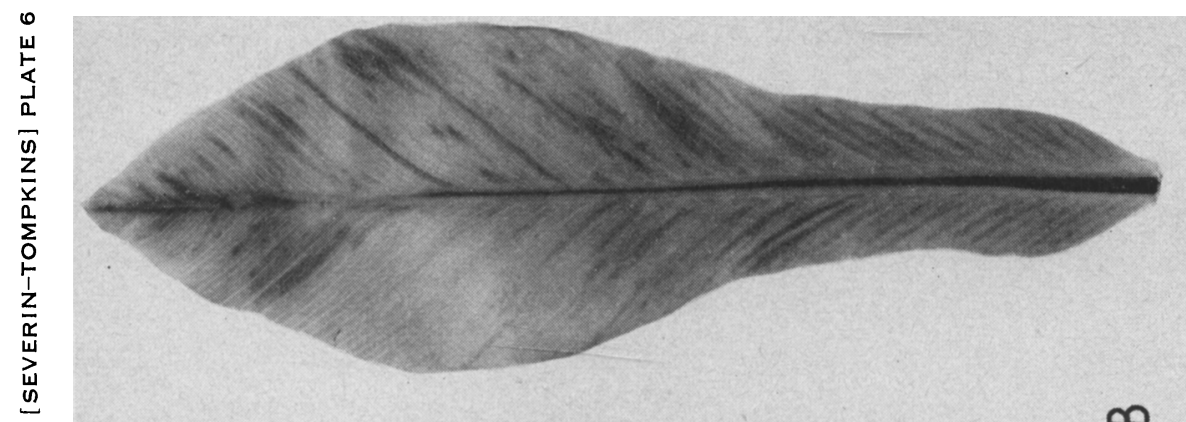

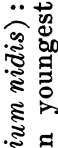

.స్ ๘ี

है:

ฟ

혼

4.

.

$\infty$
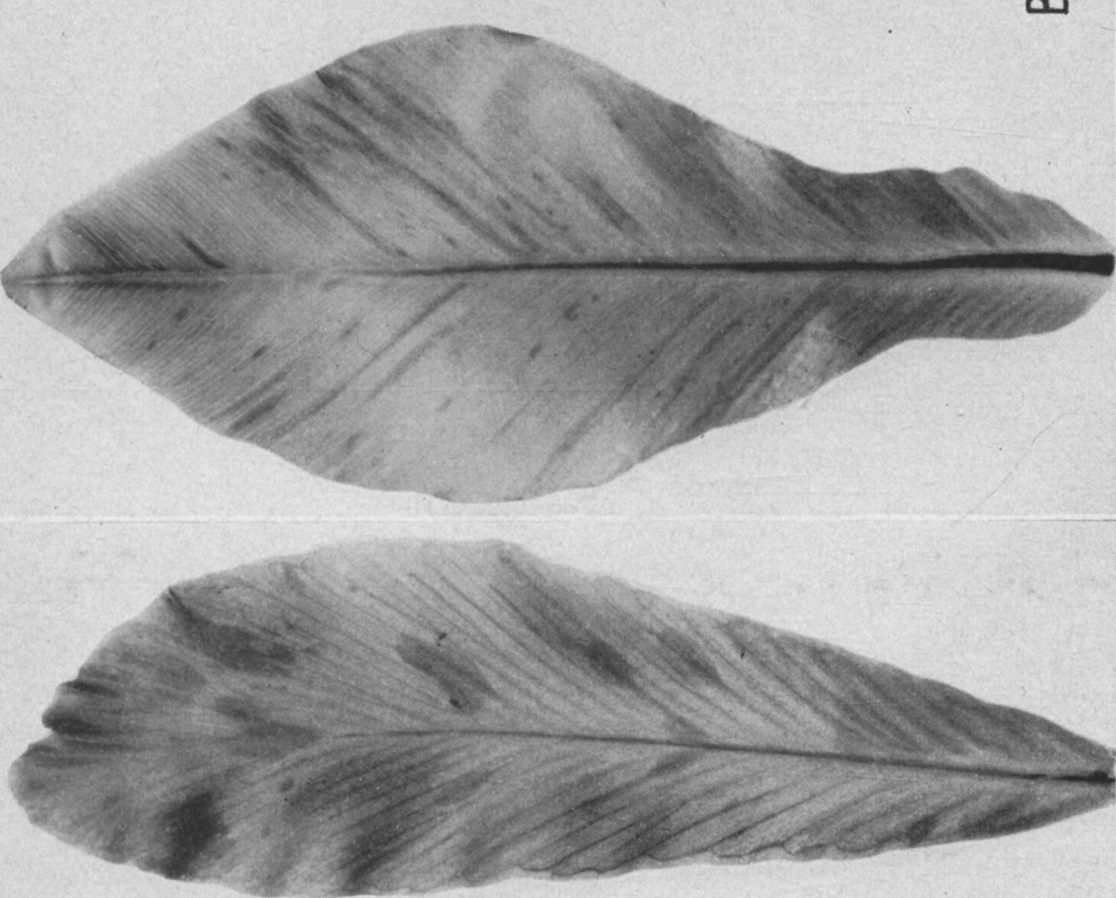

帘.

누유

옹: 뭉

난

형

蛋焉

ค

క

है

i $\infty$

롤

¿

s

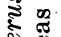

ส

옥 ్ㅠ

की

击

का न

등

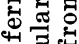

400

on

궁

요요

भ ज 50

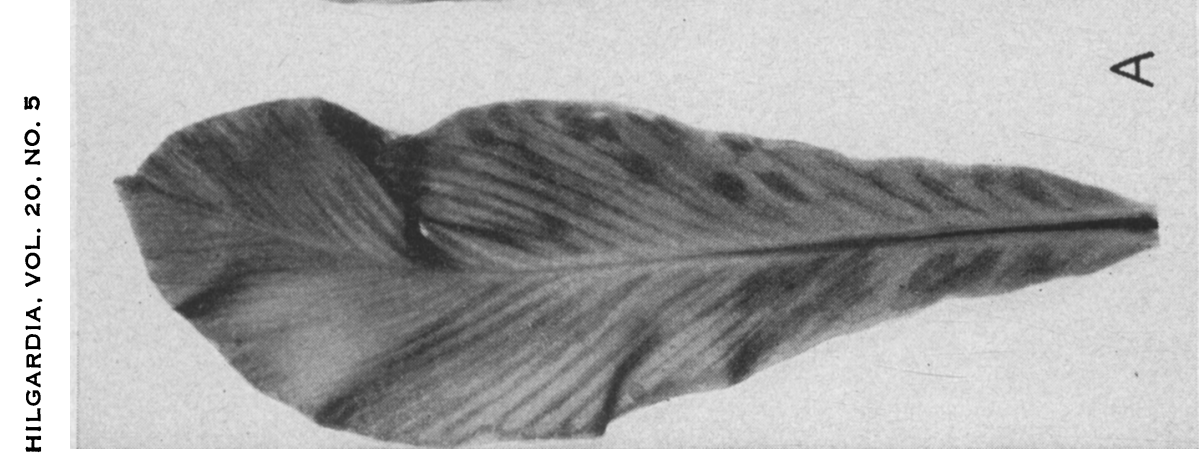

흐욤

휴

유

.

है ฮี

ํㅗㅇㅠ.

음

हैं क्ष

-

역

密

A 
The journal Hilgardia is published at irregular intervals, in volumes of about 600 pages. The number of issues per volume varies.

Subscriptions are not sold. The periodical is sent as published only to libraries, or to institutions in foreign countries having publications to offer in exchange.

You may obtain a single copy of any issue free, as long as the supply lasts; please request by volume and issue number from:

\section{Publications Office \\ College of Agriculture \\ Berkeley 4, California}

The limit to nonresidents of California is 10 separate issues on a single order. A list of the issues still available will be sent on request. 